\title{
Three permanent objectives of information systems planning
}

\author{
J. Mende \\ Department of Accounting, University of the Witwatersrand, P.O. Box 1176, Johannesburg 2000, Republic of South Africa
}

Received 1 May 1986; accepted 15 October 1986

\begin{abstract}
Since the top-down/bottom-up clash of the early 1970s, IS planning has been a subject of persistent controversy. The lack of consensus is symptomatic of weaknesses which demand evaluation and reconstruction of available theory. To provide a stable foundation for such efforts, the basic purposes of the planning process are re-examined. The analysis is based on an open model of the organizational information system - the set of all manual and computer-based systems that produce information in a firm. This model suggests that overall viability depends upon the relationships between system outputs and their users; system inputs and their sources; and systemic processes and their input/outputs. The three concepts effectiveness, economic efficiency, and technical efficiency are defined as success criteria of these relationships, and their impact on overall system viability has been expressed in a simple algebraic formula. In a dynamic environment, the formula predicts that overall viability will continually decline unless there are compensating increases in effectiveness, economic and technical efficiency. Thus these three success criteria constitute permanent objectives of information systems planning.
\end{abstract}

\begin{abstract}
Sedert die bo-na-onder'onder-na-bo-argument van die vroeë sewentigs, het die beplanning van inligtingsisteme in die polemiek gebly. Die tekort aan konsensus is simptomaties van swakhede wat evaluasie en rekonstruksie van die bestaande teorie genoodsaak. Om 'n stewige grondslag vir sulke pogings te skep, word die basiese doelstellings van die beplanningsproses heroonweeg.Die analise word gebaseer op $n$ model van organisatoriese inligtingsisteme - die volledige stel hand- en gerekenariseerde sisteme wat inligting in die maatskappy voorsien. Hierdie model impliseer dat globale lewensvatbaarheid berus op die interafhanklikheid tussen sistemiese uitvoere en hul verbruikers; sistemiese invoere en hul bronne; en sistemiese prosesse en hul invoer'uitvoer. Die drie konsepte van doeltreffendheid, ekonomiese, en tegniese doelmatigheid word gedefinieer as kriteria vir sukses van hierdie interafhanklikes en die impak daarvan op die lewensvatbaarheid van die totale sisteem. word algebra ies geformuleer. In 'n dinamiese omgewing, voorspel die formule dat totale lewensvatbaarheid toenemend agtenuit sal gaan tensy daar gekompenseer word in terme van doeltreffendheid en ekonomiese en tegniese doelmatigheid. Daarom vorm hierdie drie kriteria die permanente doelstelling van inligtingsisteembeplanning.
\end{abstract}

\section{Information systems planning}

In the 1950 s, when computers were first extensively applied in business data processing, the computer profession was preoccupied with individual programs (Head, 1963). Applications development people proudly referred to themselves as 'programmers', and they regarded their role primarily as that of devising programs.

Such programs are usually interdependent (Benjamin,1972). For example, even a simple data processing job such as Debtors Accounting consists of several programs working in unison, transferring data to each other and sharing common data files. Therefore, in the 1960 s, the concept of a 'system' of programs gained widespread recognition and 'systems analysts' joined the ranks of the computer profession in large numbers.

Then in the late sixties and early 1970s it became evident that systems too are interdependent. For example an Orders System typically transfers sales data to Debtors Accounting and shares a common product file with the firm's Stock System (Pescow, Horn \& Bachman, 1973). Therefore an 'insular' policy of developing each system in isolation of the others was nolonger tenable. Systems were now required to integrate with each other(Blumenthal, 1969: 22).

Therefore it became necessary to think in terms of a higher-order concept (Short, 1985) - the 'federation' of all computer based systems. Correspondingly there was a need for a third task - 'information systems planning' to deal with problems of systems-interdependence (Blumenthal, 1969: 2).

\section{Planning objectives}

The information systems planning task has been surrounded by controversy. For example, in the 1970 s advocates of the 'top down' strategy clashed with proponents of the 'bottom-up' approach (Nolan, 1971). Now, in the 1980s, methodologies such as 'strategic grid' contend with 'strategic fit'; 'business systems planning' with 'critical success factors', and so on (Bowman, Davis \& Wetherbe, 1983). Planning remains the primary issue in the Information Systems field (Dickson, Leitheiser, Wetherbe \& Nechis, 1984).

Is this divergence of thought the result of error, or are the different approaches merely partial views of one and the same underlying truth? Have their authors solved the same problem with varying degrees of success, or have they unwittingly addressed different situations? These questions suggest that much work still remains to be done before a satisfactory theory of IS planning is established. Existing approaches need to be tested, reconciled, integrated and perhaps discarded. New approaches may have to be devised where existing ones fail.

To provide a conceptual foundation for such endeavours, this article explores the essential purposes of information systems planning - i.e.' general ... objectives which describe the desirable attributes of company-wide information system development ... rather than the specific objectives of particular projects' (Doll \& Ahmed, 1984). It re-examines the nature of the entity that is to be planned, identifies the consequent objectives of the IS 
planning process, and indicates some of their potential uses.

\section{The object to be planned}

Fundamental to the entire planning process - strategy formulation, information requirements analysis, resource allocation, etc. - is the question what is being planned ?

At the time the need for planning arose, interdependence problems were felt most acutely in the development of systems which tapped the files of transaction processing systems to produce information for management purposes. So systems-interdependence became associated with managerial information, and the concept of a systems federation was embedded in the term management information system. For example, two authors described an MIS as

'the total complex in which data are generated, processed and refined toproduce the information needed at all levels of the organization for management purposes' (Limberg, 1967).

- 'a cluster of business information systems' (Hanold, 1972).

However, this accidental association between integration and MIS has several drawbacks. Firstly, the term MIS is ambiguously employed in referring both to the federation of systems as well as the individual member of a federation. For example

"The" management information system for an entire organisation must be visualised ... as a federation of management information systems' (Schwartz, 1970). Secondly, some members of the federation - e.g. wages and invoicing systems - produce information which is definitely not intended for management consumption, but for use at the operational level. And others, such as Debtors Accounting and General Ledger, produce information primarily aimed at customers and shareholders. Therefore the 'management' component of the term MIS is misleading when applied to the set of all computer based systems.

These drawbacks are so severe that a new term is needed to denote the object of planning.

\section{The organizational information system}

In quest of a more suitable name, let us consider precisely what is affected when planning a firm's informational future. The question is: Which processes in the firm can directly be altered by an information systems plan?

Obviously, the plan can affect all systems that produce information for use by the firm's management. But it can also impact those that support the operational level within the firm, as well as processes that provide information to customers, shareholders, etc. Therefore the IS plan alters the set of all processes that produce information in a firm.

Less obviously, the plan affects not only the new processes that will be installed in the future, but also the existing processes that will be replaced. The former include systems based on modern information technology - telecommunications, office automation as well as computers (McFarlan, McKenney \& Pyburn, 1983). The latter include current manual data processing procedures, semi-automated and computer-based systems.

So the object of IS planning encompasses all manual, semi-automated and information technology based systems that produce information for use by operational and managerial functions within the firm as well as external parties that interact with the firm. The term 'Organizational Information System' (OIS) is suggested as a name for this set of systems (Ahituv \& Neumann, 1982: 139).

\section{Open system model}

AnOIS is an 'open system' which exchanges resources with an environment (Davis \& Olson, 1984: 275). The environment comprises the host firm plus the customers, suppliers and other entities with which the firm interacts. The system inputs resources such as labour, equipment, procedures and data from sources in the environment. In return, users in the environment receive information from it. These exchanges are shown in Figure 1.

To survive as an economic entity, the OIS ought to produce outputs whose value to the environment exceeds the cost of the resources provided by the environment. Suppose the cost of the input resources can be reduced to an annual amount $r$ (apportioning the costs of capital items such as hardware and software over the duration of their useful lives). And let the annual informational value be represented by $v$. Then economic viability demands that the ratio $v / r$ at least exceed 1 , and ideally should be as large as possible.

Therefore the ratio of annual informational value to resource cost constitutes an overall criterion of OIS success:

Viability $=v / r$.

Without demanding that we measure it numerically, this

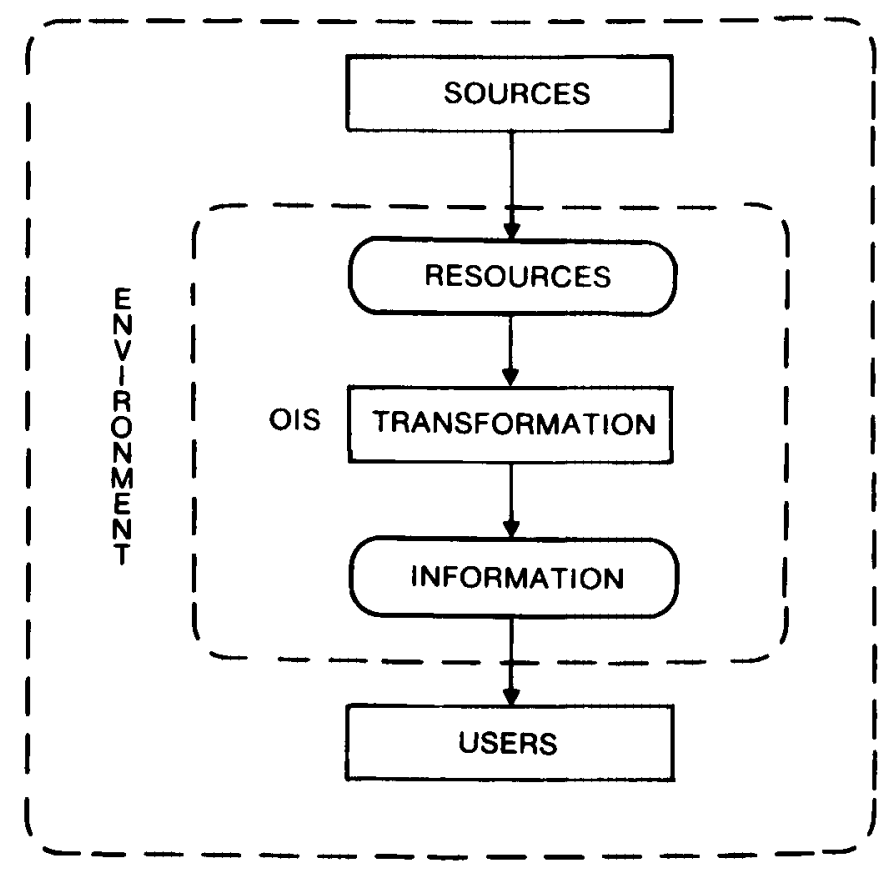

Figure 1 Open system model of an OIS 
ratio provides a conceptual basis for abstract reasoning about the kinds of things that require attention in order to improve an organizational information system.

\section{Determinants of viability}

The information system planner can influence OIS viability by manipulating three distinct relationships between the components shown in Figure 1.

Firstly, there is the relationship between users and the information they receive. Users assign a high, medium or low value to the system's outputs by assessing - not the elegance of the transformation processes - but the relevance of the outputs to their business activities. For example, they would ask how much the outputs help them in planning, in marketing, in manufacturing, etc.

Therefore the annual informational value $v$ can be enlarged by increasing the degree of correspondence between OIS outputs and users' real information needs.

Secondly, the resource cost $r$ is primarily affected by the relationship between resource inputs and their environmental sources. For example, if the system employs too much labour and too little technology, $r$ may be unnecessarily high. Similarly if it obtains equipment from an exorbitant supplier, $r$ would also be excessive.

Therefore the resource cost can be reduced by choosing a more appropriate mix of potential resources offered by available sources.

Thirdly, both $r$ and $v$ depend on the processes of transforming inputs into outputs. Any wastage of input resources - for example, laggard operators or malfunctioning software - will unnecessarily inflate $r$. Similarly $v$ is diminished by waste in the output - for example, lengthy response times in online information retrieval.

Therefore the viability ratio $v / r$ can be increased by eliminating waste in the transformation processes at the core of Figure 1.

\section{Effectiveness and efficiency}

These relationships can be translated into conceptual criteria of an organizational information system's success by conducting three thought experiments.

Firstly, consider an actual OIS which has evolved over the years in a firm whose information systems personnel were not fully aware of users' real information needs. Therefore the system's informational value, $v$, would be unduly low. Alternatively, suppose a similar set of systems had been established with perfect knowledge of users' needs. Then the hypothetical OIS would produce a superior mix of informational outputs, whose value $v$ ' is a maximum. Aocordingly the ratio

$$
\boldsymbol{N}=\boldsymbol{v} / \boldsymbol{v}^{\prime}
$$

reflects the extent to which the actual OIS satisfies users' information needs. This ratio, which varies from 0 to $100 \%$, is related to the well- known concept 'effectiveness' (Davis \& Olson, 1984: 287), and will hereafter be referred to by that name.

Secondly, consider an actual OIS which obtains its resource inputs from a selection of sources costing an excessive amount $r$. Altematively suppose an ideal system had been developed, which inputs a resource mix of minimum cost $r^{\prime}$. Then the ratio

$$
E=r^{\prime} / r
$$

which also ranges from 0 to $100 \%$, reflects the actual system's utilization of available sources. It is related to the concept 'economic efficiency' (Cole, 1973: 120), and is defined as such.

Thirdly, consider an actual OIS whose transformation processes unnecessarily waste a proportion of the inputs in producing informational outputs. Therefore its resource $\operatorname{costs} r$ will be unduly high, and its informational value $v$ will be unnecessarily low. In comparison, an ideal system (which involves no waste) would consume fewer resources - costing a smaller amount $r$ " - and would produce more information, of greater value $v^{\prime \prime}$. The ratio

$$
T=\left(r^{\prime \prime} / r\right) \cdot\left(v / v^{\prime}\right)=\left(r^{n} \cdot v\right) /\left(r \cdot v^{\prime}\right)
$$

therefore indicates the degree of waste in the actual OIS. This is the 'technical efficiency' (Cole, 1973: 120).

\section{Impact on overall viablity}

The ratios effectiveness, economic efficiency, and technical efficiency measure OIS suocess in three independent dimensions. Therefore a technically efficient system may be ineffective and economically inefficient; or an effective system may be technically as well as economically inefficient, and so on. The combined impact of the three independent variables $N, E$, and $T$ on overall economic viability can be determined by another thought experiment, based on prior research in education (Mende, 1981). The experiment traces the growth in the viability ratio of an imperfect system as it is successively improved - optimizing first the effectiveness $N$, then the economic efficiency $E$, and finally the technical efficiency $T$.

Step 1. Suppose outputs are modified to match users' needs as closely as possible, thereby increasing informational value from $v$ to $v$ '. Then system effectiveness $N$ is $v / v^{\prime}$, and overall viability changesfrom $v / r$ to $v ' / r$, where

$$
v / r=\left(v / v^{\prime}\right) \cdot\left(v^{\prime} / r\right)=N \cdot\left(v^{\prime} / r\right)
$$

Step 2. Suppose the mix of inputs is modified to make optimal use of available resources, reducing resource costs from $r$ to $r^{\prime}$. Then economic efficiency $E$ is $r^{\prime} / r$, and overall viability changes from $v^{\prime} / r$ to $v^{\prime} / r^{\prime}$, where

$$
v^{\prime} / r=\left(v^{\prime} / r^{\prime}\right) \cdot\left(r^{\prime} / r\right)=E \cdot\left(v^{\prime} / r^{\prime}\right)
$$

Step 3. Suppose all waste is eliminated from the transformation processes, increasing informational value from $v^{\prime}$ to $v^{\prime \prime}$ and decreasing resource costs from $r^{\prime}$ to $r$ ". Then technical efficiency $T$ is $\left(r^{\prime \prime} . v^{\prime}\right) /\left(r^{\prime} . v^{\prime \prime}\right)$, and overall viability changes from $v^{\prime} / r^{\prime}$ to $v^{\prime \prime} / r^{\prime \prime}$, where

$$
v^{\prime} / r^{\prime}=\left(v^{\prime \prime} / r^{\prime \prime}\right) \cdot\left(r^{\prime \prime} \cdot v^{\prime}\right) /\left(r^{\prime} \cdot v^{\prime \prime}\right)=T \cdot\left(v^{\prime \prime} / r^{\prime \prime}\right)
$$


Substituting equations (2) and (3) into (1):

$$
\begin{aligned}
v / r & =N \cdot\left(v^{\prime} / r\right) \ldots \ldots \ldots \ldots \ldots \ldots . . .6 \text { by equation }(1) \\
& =N \cdot E \cdot\left(v^{\prime} / r^{\prime}\right) \ldots \ldots \ldots \ldots \ldots \text { by equation }(2) \\
& =N \cdot E \cdot T \cdot\left(v^{\prime \prime} / r^{\prime \prime}\right) \ldots \ldots \ldots \ldots \text { by equation }(3) .
\end{aligned}
$$

Therefore the imperfect system's viability ratio $(v / r)$ can now be expressed in terms of the ideal system's ratio $\left(v^{\prime \prime} / r^{\prime \prime}\right)$ by the formula:

$$
v / r=N \cdot E \cdot T \cdot\left(v^{\prime \prime} / \sigma^{\prime \prime}\right) \text {. }
$$

This means that the ideal viability $(v / r)$ of an organizational information system is reduced by the product of the effectiveness, economic efficiency, and technical efficiency.

\section{Planning objectives}

The fact that these criteria effect overall viability by multiplication rather than addition has significant implications. To illustrate, consider an OIS which scores an apparently acceptable $80 \%$ on each criterion. Then

$$
\text { N.E.T. }=(0,8)^{3}=0,5 \text {. }
$$

Therefore the actual viability ratio is not a healthy $80 \%$ of the ideal, but is reduced to a mere half of its potential value.

Alternatively suppose the three ratios are all $95 \%$. Then

$$
N . E . T .=(0,95)^{3}=0,86 \text {. }
$$

Therefore a high level of viability demands very high levels of effectiveness, technical efficiency, and economic efficiency. Therefore it is necessary to ensure near-optimality on each independent dimension of success: otherwise the viability ratio can easily dwindle to an uneconomic level. This is a matter for planning.

Consequently the three ratios effectiveness, economic efficiency, and technical efficiency constitute simultaneous objectives to be achieved by the information system planning process.

\section{Continual deterioration}

These three objectives can never fully be achieved, because 'All systems deteriorate over time' (Martin \& Trumbly, 1986). No sooner has one established a nearperfect organizational information system than the environment changes, opening up the gap between actual and potential viability.

Consider the user environment. As time goes on, methods of manufacturing, logistics, marketing, finance, and management constantly improve. This causes changes in business practices, both internally in the firm and externally among customers, shareholders, etc. And these changes in turn cause existing outputs to lose relevance to the users' activities. Therefore actual informational value $v$ decreases. So, unless informational outputs are continually upgraded to keep pace with the environmental changes, the effectiveress $v / v^{\prime}$ will steadily decline.
Similarly progress in the source environment affects the economic efficiency. As suppliers develop cheaper, more powerful hardware and software they withdraw support for outdated equipment and software. Therefore the actual resource cost $r$ increases. Therefore, unless the input mix is periodically adjusted to incorporate new technology, the economic efficiency $r^{\prime} / r$ will also decline.

Technical efficiency is not exempt either. On the one hand, obsolescence increases hardware and software maintenance requirements, inflating the resource cost $r$. On the other, increasingly frequent breakdowns, impatience with user-unfriendly software, etc. will diminish informational value $v$. Without perpetual renewal of the transformation processes at the core of the OIS, the technical efficiency $\left(r^{\prime \prime}, v\right) /\left(r . v^{\prime \prime}\right)$ will therefore decline as time goes on.

To counter the continual erosion in viability, ongoing efforts are therefore recessary to secure compensating increases in OIS effectiveness and efficiency. Otherwise the viability ratio $v / r$ will steadily deteriorate.

\section{Theoretical applications}

Accordingly the three concepts effectiveness, economic efficiency, and technical efficiency represent broad planning objectives that are likely to endure for many decades in the future. Their permanency and broad scope recommend them as a stable foundation for the development of information system planning theory.

Firstly, they can be employed as unifying umbrella concepts that allow large numbers of more specific objectives to be encompassed in one term. For example, the economic efficiency concept includes subsidiary objectives such as increased automation, hardware compatibility, etc. Similarly technical efficiency subsumes objectives such as hardware utilization, data sharing, etc. And effectiveness encompasses subsidiaries such as information availability, timeliness, etc.

Secondly, the three objectives can be used to evaluate and reconcile suggested information system planning strategies. For instance, if a particular strategy appears to be preoccupied with one of the three objectives and ignores the other two, then it needs to be augmented. For example, the old 'top-down' strategy (Zani, 1970) is primarily concerned with effectiveness, and is therefore incomplete. Similarly the 'bottom-up' strategy (Schwartz, 1970) focuses mainly on technical efficiency and so is also incomplete. Consequently a merger of the two is indicated (Davis, 1974: 409).

Thirdly, the trio can be employed as conceptual variables (Ives, Hamilton \& Davis, 1980) in relationships between the organizational information system and elements of its environment. These relationships can then be used as premises for identifying problems and deducing new strategies of information system planning (Mende, 1986).

\section{Practical applications}

Although primarily intended for use in developing the theory of information system planning, the foregoing can also be applied in practice. Such applications are unlikely 
to be quantitative, as $r^{\prime}, v^{\prime}, r^{\prime \prime}$, and $v^{\prime \prime}$ are not directly measurable. For measurable conceptions of effectiveness, see Ives, Olson \& Baroudi (1983), as well as Hamilton \& Chervarny (1981). However, there are several qualitative uses.

Viability's triple dependence on effectiveness, technical efficiency, and economic efficiency reminds one to consider all three criteria and avoid a fixation on a single one of them. Therefore the trioprovides a conceptual framework for multiple-criterion decision making.

Firstly, the three concepts can be applied in assessing an organization's current information systems. For example, a classification of strengths and weaknesses relating to each distinct criterion quickly identifies major imbalances such as a predominance of weaknesses on the effectiveness dimension.

The trio can be used in objective setting as well. Specific planning objectives can systematically be listed under three headings - effectiveness, technical efficiency, and economic efficiency. This ensures that none of the major dimensions of OIS viability is accidently overlooked. Success depends on the scope of IS planning (Kimmerly, 1983).

Thirdly, the three objectives can also be employed in project selection and ranking. The benefit of each candidate for inclusion in the plan can be evaluated in terms of its contributions to increased effectiveness, increased technical efficiency, increased economic efficiency. Then one can use the estimate to select a portfolio of projects by means of techniques such as Net Worth (Mende, 1984) or scoring (Melone \& Wharton, 1984). Thereafter, projects can be ranked in priority sequence using methods such as the 'series criterion' (Mende, 1985) or the nine-square grid (Buss, 1983).

\section{Conclusion}

So, although unmeasurable, the three criteria effectiveness, economic efficiency, and technical efficiency can usefully be employed in Information Systems Planning. By encapsulating the complex relationships between sources, users, and the system in three simple terms, they provide us with conceptual tools which facilitate abstract reasoning about information systems. The multiplicative connection between them sensitizes us to the danger of preoccupation with one relationship to the exclusion of the others. Prone to continual deterioration, they constitute permanent targets for practical information systems planning, and provide a stable foundation for the development of IS Planning theory.

\section{References}

Ahituv, N. \& Neumann, S. 1982. Principles of information systems for management. Dubuque, Iow'a: Wm.C. Brown, $528 \mathrm{p}$.

Blumenthal. S.C. 1969. Management information systems. Englewood Cliffs, N.J: Prentice-Hall, 219p.

Bouman, B., Davis, G. \& Wetherbe, J. 1983. Three-stage model of MIS planning. Inf. Managem., vol.6, 11-25.
Buss, M. 1983. How to rank computer projects. Harv. Bus. Rev., vol.61(1), 118-125.

Cole, C.L. 1973. Microeconomics. New York: Harcourt Brace Jovanovich, 488p.

Davis, G.B. 1974.Management information systems. New York:McGraw-Hill, 482p.

Davis, G.B. \& Olson, M.H. 1984. Management information systems. 2nd Edition. New York: McGraw-Hill, 693p.

Dickson, G., Leitheiser, R., Wetherbe, J. and Nechis, M. 1984. Key information systems issues for the 1980s. MIS Quart., vol.8, 135-159.

Doll, W. \& Ahmed, M. 1984. Objectives for systems planning. J.syst. Managem., vol.35(12), 26-31.

Hanold, T. 1972. An executive view of MIS. Datamation, vol.18(11), 65-71.

Hamilton, S. \& Chervany, N. 1981. Evaluating information systems effectiveness. MIS Quart., vol.5, 55-68 and $79-86$.

Head, R. 1963. Real-time programming specifications. Comm. $A C M$, vol.6, 376-379.

Ives, B., Hamilton, S. \& Davis, G.B. 1980. A framework for research in computer-based management information systems.Managem. Sci., vol.26, 910-934.

Ives, B., Olson, M. \& Baroudi, J. 1983. The measurement of user information satisfaction. Comm. $A C M$, vol.26, 785-793.

Kimmerly, W.C. 1983. Planning pitfalls.Datamation, vol.29(10), 208-210.

Limberg, H. 1967. How to meet management's information needs. In: 'Ideas for Management', Association for Systems Management.

Martin, M. \& Trumbly, J. 1986. Measuring performance of automated systems. J. Syst. Managem., vol.37(2), 7-17.

McFarlan, F.W., McKenney, J. \& Pyburn, P. 1983. The information archipelago - plotting a course. Harv. Bus. Rev., vol.61(1), 145-156.

Melone, N.P. \& Wharton, T.J. 1984. Strategies for project selection. J. Syst. Managem. , vol.35(2), 26-33.

Mende, J. 1981. Developing instructional systems. The Commerce Teacher, vol.13, 10-25.

Mende, J. 1984. A viability criterion for computer system development projects. S.Afr.J.Bus.Mgmt., vol.15, 144- 149 .

Mende, J. 1985. A priority criterion for serial computer system development projects. S.Afr.J.Bus.Mgmt. , vol.16, 55-60.

Mende, J. 1986. Some problems of information systems planning. Univ. of the Witwatersrand: working paper.

Nolan, R.L. 1971. Systems analysis for computer based information system design. Data Base, vol.3(4), 1- 10.

Pescow, J., Horn, J. \& Bachman, M. 1973. Handbook of successful data processing applications. Englewood Cliffs, New Jersey: Prentice-Hall, 356p.

Schwartz, M.H. 1970. MIS Planning. Datamation, vol.16(10), 28-31.

Short, R. 1985. Levels of abstraction and systems hieranchies. Univ. of the Witwatersrand: working paper.

Zani, W.M. 1970. Blueprint for MIS. Harv. Bus. Rev., vol.48(6), 95-100. 